Notre Dame Law School

NDLScholarship

1990

\title{
The Legal Status of Agro-Industrial Units and Their Relations With the Owners and Tillers of Land
}

Conrad Kellenberg

Notre Dame Law School

Follow this and additional works at: https://scholarship.law.nd.edu/law_faculty_scholarship

Part of the Agriculture Law Commons

\section{Recommended Citation}

Conrad Kellenberg, The Legal Status of Agro-Industrial Units and Their Relations With the Owners and Tillers of Land, 38 Am. J. Comp. L. Supp. 207 (1990).

Available at: https://scholarship.law.nd.edu/law_faculty_scholarship/19

This Article is brought to you for free and open access by the Publications at NDLScholarship. It has been accepted for inclusion in Journal Articles by an authorized administrator of NDLScholarship. For more information, please contact lawdr@nd.edu. 


\section{CONRAD KELLENBERG}

\section{The Legal Status of Agro-Industrial Units and Their Relations With the Owners and Tillers of Land}

\section{OVERVIEW - AGRIBUSINESS IN THE UNITED STATES}

Agro-industrial enterprises have always been permitted by United States law, both national and state. They have a long history in this country, although they have become more prominent in recent decades.

American law has tended in a variety of ways to encourage the creation of agro-industrial enterprises. At the same time, American law has tended to discourage the family farm:

Of course, there are many family farm owners who have incorporated their farm businesses, largely for purposes of taxation and continuity. However, for the rest of this report I shall be focusing on corporate agricultural activity that is engaged in by larger corporate entities.

These enterprises are increasingly characterized by vertical integration of companies at two or more steps in food production and merchandising, viz., growing, processing, canning, warehousing, transporting, wholesaling, and retailing. In addition, there is a fair amount of horizontal integration of companies at every step. Moreover, in recent years, as a result of mergers and takeovers of large enterprises, and the disappearance of smaller ones, there has been a strong movement toward oligopoly in the United States food business.

These developments have had certain discernible consequences already. There may be more in the future. Lawyers should think about them.

\section{NON-GOVERNMENTAL AND GOVERNMENTAL INFLUENCES ENCOURAGING AGRIBUSINESS}

Probably the two major factors responsible for the increased dominance of agro-industry in the United States are the technological revolution and the economic system of capitalism. These have 
influenced private initiatives toward agro-business, and also governmental measures, in the United States.

The introduction of mechanized farm equipment in the last century and the first half of this one displaced many agricultural workers, the descendants of some of whom are unemployed and living on public welfare payments in our inner cities. It also caused family owners who could not, or did not want to, invest in such equipment to sell their farms. In the last decade, some of our more prosperous family farm owners have overinvested in expensive farm equipment and have lost their farms as a result. The greatly increased use of chemical herbicides and pesticides has also tended to displace farm labor. These voids have been filled by agro-industry.

Capitalism causes business organizations to search constantly for profitable ventures. Americans spend a good deal of their personal income on food, although not so high a percentage of their personal income as people of some other countries do. Changes in American lifestyles have made it less common for them to invest time in food growing; processing, and cooking. There are profits to be made at all stages of the food business, and corporations have been attracted.

Secondly, capitalism has a natural tendency toward bigness of organization and concentration of wealth. Large, wealthy organizations have advantages in the market. They have the power to buy cheaper and sell dearer. Large national companies can withstand shocks, such as crop failures in certain geographical areas, more easily than smaller local companies. They can through advertising influence the food' demands of a sizeable proportion of the American people. Moreover, they can influence national and state governments and the laws passed by those governments.

Even without corporate lobbying efforts, our national and state legislators, judges, and administrators have generally assumed the desirability of technology and of capitalism. American law for these reasons has usually tended to encourage agribusiness enterprises and to discourage family farms.

More specifically, government spending on agriculture has tended to benefit the larger and wealthier farms. There have been many such spending programs. An important policy of our national government has been to increase American food production. The first purpose is to make available more and cheaper food to the American people. The second purpose is to provide more agricultural products for sale abroad, especially as demand for other American products has fallen. Subsidies in the form of price supports and water for irrigation have been given in such a way as to benefit large landowners more than small ones. Government research and development programs have done the same. 
Government income tax laws have, through their rates and deductions, made farms useful as tax shelters for wealthy individuals and corporations.

National and state governments have also tended to benefit the large and wealthy through liberal corporation laws, minimal enforcement of anti-trust laws, and rules and practices in administering public lands that are rented to private parties for agriculture.

On the other hand, the family farm has been mostly hurt by government - sometimes by the presence of bad laws, and sometimes by the absence of good ones. To benefit family farms, for example, commodity and insurance programs should be structured so that family farmers can obtain an adequate annual income, and so that no one gets payments in excess of that amount. Family farmers, especially low-income farmers, should be given better access to basic human services. New families should be encouraged to enter farming, and the competitive position of existing small farmers should be improved by grants or low-interest loans, technical assistance, and training. Credit programs should be more carefully structured to preclude discrimination. The thrust of agricultural reasearch should be directed toward affordable and appropriate technology.

Tax laws that stimulate farm expansion, that favor large operations, that tax farm profits without regard to ability to pay, and that encourage absentee ownership and speculation in agricultural land should be changed if family farmers are to be benefited. Tax rates, credits, and allowances that encourage farm expansion and are available primarily to farmers and investors with high incomes should be withdrawn. Farmland should be assessed for property tax purposes according to its productive value for agriculture, and the rates should be graduated to discourage larger landholdings. Estate taxes on family farm owners should permit and encourage inheritance by children rather than sale to pay taxes.

Anti-trust laws that bear on the activities of large, investorowned corporations, especially those engaged in food production, processing, and marketing should be enforced strictly.

Other governmental measures that would have to be reoriented if they were to favor family farms rather than large agro-industrial enterprises could be easily added to the foregoing.

\section{ACQUISITION AND USE OF LAND BY AGRIBUSINESSES}

The body of American law affecting the acquisition of land is basically laissez-faire. Free enterprise and freedom of contract generally govern sales, rentals, and lending. The market is allowed to control prices, terms and conditions, and even the uses to which the 
land will be put within the broad limits set by zoning. Thus, those who have the market power conferred by size and wealth are in the best position. There is relatively little regulation of land acquisition by law, except for some regulation of agricultural land ownership by foreign citizens and corporations.

It is not surprising, then, that the direction of land ownership in the United States in recent years has been toward concentration. Wealthier farmers buy out poorer ones, and are in turn bought out by agribusinesses. Farms have declined in number and increased in size. The farm population has been substantially reduced.

American agribusiness companies sometimes purchase the land on which they will grow crops or raise animals. Sometimes they rent the land instead, on a cash-rent basis. They do not engage to any significant degree in the other forms of land rental, such as share-cropping.

Sometimes, instead of engaging in the production of food, American agro-industrial companies contract with intermediate business enterprises, such as storage facilities or processor-canners, which then enter other contracts with family farmers for a supply of crops or animals.

Sometimes agro-industrial companies contract directly with those farmers.

Thus, there is no single method that they employ in acquiring land or the produce of the land. But all of the methods operate within a legal system that encourages freedom of contract. This situation generally benefits the large and the wealthy, who have the power to be successful in market negotiations.

With regard to the purposes for which land is acquired and the methods of cultivation used after acquiring it, the question of the environment arises. Here again, American law is relatively permissive. Americans acquired from the original inhabitants an immense and fertile land. Until the last few decades, family farmers on the whole took decent care of it. But huge increases in the use of chemical fertilizers, herbicides, and pesticides, have caused environmental degradation of American soil, air, and surface and underground water. Water pollution has also resulted from soil erosion caused by certain tilling methods, from irrigation water runoff, from overgrazing, and from animal feedlots. Irrigation practices are also draining underground aquifers, such as the Ogallala Aquifer under the central states.

There is some, although conflicting, evidence to support the view that agribusiness executives and boards of directors are more concerned with the size of company profits during their short tenures than they are with long-term fertility and sustainability. 
To the credit of American lawmakers, they are now beginning to understand the nature and extent of agricultural environmental problems, and may take steps to try to solve them.

However, few lawmakers seem to recognize that American farming is probably the most inefficient in the world in terms of the amount of land and the amount of energy used to obtain each unit of food energy. It is "efficient" only in requiring the least amount of human labor.

\section{Changes IN THE POSITION OF FARMERS AND AGRICULTURAL WORKERS}

What changes have occurred in the status of land cultivators and workers, and have those changes a relation to agro-industrial enterprises and to agrarian law?

Family farmers who own their land, or who own most of their land and rent additional land from longtime neighbors, seem to possess a certain self-sufficiency and stability, even when they lack the economic security of high incomes. Those whose financial position gives them relatively equal bargaining power with food processors and distributors are even more fortunate.

On the other hand, to have to sell one's land or farm produce to an economically powerful agro-industrial enterprise sharply reduces the stability of the landowner and his family. Even having to take an off-farm job has some effect, and rnost family farmers in the United States now get a large percentage of their income from offfarm sources. To the extent that American law tolerates these recent developments, it is no friend of the family.

As for agricultural workers, American law has never been a friend to them. Most agricultural workers have been excluded from national and state laws providing econornic security, such as old age insurance, unemployment compensation, wage laws, and labor relations laws. Some health and safety protections involving farm equipment and housing exist in the lav. Some, such as increased protection against toxic pesticides, are being fought for. Immigration laws affecting farmworkers have traditionally tended to be enforced or not enforced with more consideration for the economic benefit of Americans than for the welfare of immigrant farmworkers.

Is the position of agricultural workers likely to worsen if they work for agro-industrial enterprises rather than for family farmers? Are those enterprises more likely to view agricultural workers only as factors of production leading to increased profits rather than as persons? Are those enterprises more likely to be able to prevent the passage of protective laws by political contributions to lawmakers, or 
by bragging about the number of jobs they provide? Perhaps, but the evidence is uncertain.

\section{Results AND Future Prospects}

What are the results of the recent growth of agro-industrial enterprises in the United States? It is perhaps too early to predict. But some writers argue that American legislators, and the executives and directors of American companies, have short perspectives. These observers say that American governments and the American food industry are more interested in short-term benefits to themselves than in the sustainability of American resources or the longterm welfare of the American people. Some of these writers consider big agribusiness to be dangerous even to the American food consumers, who are said to be overweight and prone to heart disease because sweet and fat-laden "junk foods" tend to be more profitable than nourishing foods.

The future prospect is unclear. Some, peering into the fog, see this picture: American agribusiness companies - with at least tacit support from American law - continue to concentrate American farmland ownership. Industrial pollution in the long term almost brings to an end the Industrial Revolution. In the largely agricultural society that follows, the majority of Americans end up working for a few gigantic agribusinesses that own most of the land.

Some optimists have a different scenario: American lawmakers, taking seriously scientific suggestions that heavy chemical usage will ultimately ruin the productivity of American farmland, provide incentives for less harmful methods of production. They pass laws and appropriate the money for programs to provide training in sustainable agriculture and for programs to help families own farms. Through these programs, some Americans now unemployed and susisting on public welfare payments become productively employed in agriculture. Environmental, employment, and national budget problems are all alleviated.

Various pessimistic and optimistic projections are credible. There are many variables and many possibilities. I encourage you, too, to peer through the fog at the future, and attempt to formulate rational and decent policies that can be encouraged by the law. ${ }^{1}$

1. A fuller development of the points made in this report can be found in such books as: U.S. Department of Agriculture, Structure Issues of American Agriculture (1979); U.S. Department of Agriculture, A Time to Choose: Summary Report on the Structure of Agriculture (1981); Wendell Berry, The Unsettling of America (1977); Ross Hume Hall, Food for Nought (1974); Jim Hightower, Eat Your Heart Out (1975); Mark Kramer, Three Farms (1980); Charles P. Lutz, Farming the Lord's Land (1980); and James Wessel, Trading the Future (1983). 